\title{
ICDHS 2016 TAIPEI \\ Design of an entrepreneurial model in product development and strategy for marketing of handicraft products in the northeast of India: Shken.in - craft community collectives
}

\author{
Mandar Rane / Indian Institute of Technology Bombay / Mumbai / India \\ Ravi Mokashi Punekar / Avinash Shende / Indian Institute of Technology Guwahati / \\ Guwahati / India
}

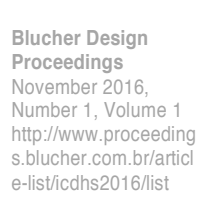

\begin{abstract}
The north east states in India is home to diverse ethnic communities who excel in bamboo and cane crafts. Often located in remote villages these communities lack access to commercial urban markets. Economic growth suffers and the community fails to translate its crafts into a successful enterprise. This paper will present design led interventions that were initiated by a design team amongst such remotely located craft communities in the north eastern hill state of Meghalaya, India. 'Restrained Technology Intervention' (RTI) model was adopted that enhanced productivity and quality standards, but retained the skill sets of the artisan community. A comprehensive community development plan was outlined that included skill assessment, craft training programs in productivity enhancement methods following the RTI approach. A branding and online marketing plan was developed which considered employment opportunities for the educated unemployed youth of the state.

Market testing was undertaken with sample production of the newly designed products to verify their acceptance amongst two leading retail-marketing agencies in the country. A unique initiative in compiling a database of the craft community resulted in celebrating identity of individual craftsman in that collective. It was envisaged that this intervention would result in bringing a sustainable business enterprise that gave direct access to every member of the craft community collectives across the state. The paper suggests that this entrepreneurial model in product development and marketing of Handicraft products can be adopted as a policy initiative for growth of the handicraft and the handloom sector. In the Indian government's new thrust on 'Make in India', such an inclusive approach has the potential to generate economic growth opportunities for the vast pool of highly skilled craft communities spread across the country.
\end{abstract}

\section{Keywords}

(RTI) Restrained Technology Intervention, handicrafts of northeast, branding for craft-products, Make in India

\section{Introduction}

Indian handicrafts embody a heritage of aesthetics, creativity and craftsmanship in their rich diversity - a living tradition that has sustained generations of people in India. The Working Group Report on Handicrafts put together by the Ministry of Textiles, Government of India (Gol) for the plan period (2012-2017) highlighted some key insights that hamper the growth of the handicraft sector in India. It estimated that we have a workforce of nearly 7 million craftpersons spread across this unorganized sector. The handicraft sector contributes to exports of handicraft from India worth nearly Indian Rupees 10000 Crores (215 million USD) per annum. The report outlined the recommendation for intervention focused on 5 key aspects:

1. The need for brand building, marketing, craft promotion, advocacy and entrepreneurship

2. Development of craft clusters infrastructure and technology

3. Schemes for Artisan welfare

4. Research, education, training, design and compliance issues

5. Plan for Inputs, credit, raw material 

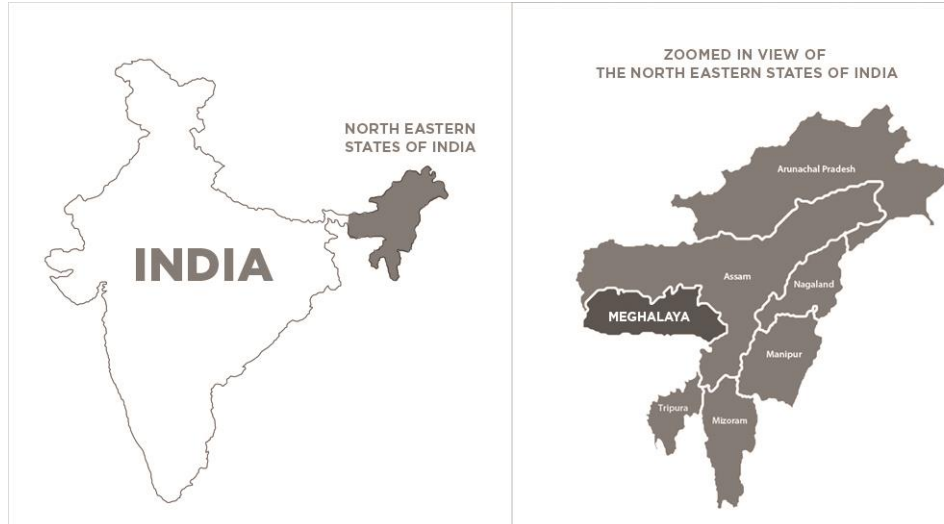

The Government of India through the Ministry of Textiles, has introduced a number of centrally funded schemes for the upliftment of Handicraft and Handloom sector in the country. Agencies like the Khadi and Village Industries Commission (KVIC) and the Directorate of Handlooms and Handicrafts through the Office of the Development Commissioner (Handicrafts), extend intervention programs including craft training, marketing fairs, social welfare schemes etc. Small financial loans are extended to Self

Fig. 1: Northeast of India (Left),

North eastern states of India, Meghalaya, India (Right) Help Groups (SHGs) to organize craft communities of 20-30 members and infrastructure support provided through Common

Facility Centres (CFCs) for groups of SHG's. The periodic training and skill up gradation workshops organized during the year get small teams of craftsmen to attend these workshops against a daily sustenance allowance. Designers empaneled with the $\mathrm{DC}(\mathrm{H})$ office are invited to conduct these training programs in new product and tool development . These schemes are more often subject to pressure of meeting the deadline of fund utilization for the financial year. However, in this process a holistic development of the sector is missed out. This paper presents an alternative integrated and holistic design led entrepreneurship model undertaken for the state of Meghalaya with a focus on bamboo crafts as a case.

\section{About handicrafts in the north eastern states}

The north-eastern states, often referred to as the seven sisters, comprise the hill states of Meghalaya, Nagaland, Manipur, Arunachal Pradesh, Tripura, Mizoram and the Assam Valley.

They form a diverse multi ethnic community of Indians and are home to more than 100 ethnic tribes who are skilled in craftsmanship and handloom traditions very distinct in their aesthetic sensibilities. These communities are spread across the different states, of which some are located in remote mountainous locations amongst the foothills of the Himalayas. Living with nature is integral to their lifestyle. The social structure is well defined with the village headman playing a distinct role in management of affairs of the village. The states have a long international border and there is a cross-cultural influence from neighbouring countries including Myanmar, China, Bangladesh and Bhutan. The entire region has an extraordinary diversity of tribal people-Arunachal Pradesh has 26 major tribes; Nagaland has 16 tribes and the state of Meghalaya, Assam, Manipur, Mizoram and Tripura has nearly 12 tribes each. Relatively cut away from the other regions of India, each state is industrially less developed but has a rich wealth of natural resources including forests, mines and biodiversity.

The 23 _ Cll initiative to improve the handloom and handicraft products of North East, Cll Delhi (2001), status report prepared by Northeast Development and Finance Corporation (NEDFi) on the Handloom and Handicraft sector in north-east India, presents the following interesting facts highlighting the importance of development of handicrafts for the economic growth of the region.

- Every 14th person in the north-eastern region is dependent on handloom and handicraft products for a livelihood.

- Nearly $80 \%$ of income for the artisan comes from the handloom and handicraft sector.

- More than $90 \%$ livelihood to nearly $60 \%$ of the artisan community comes from handloom and handicraft sector.

- Share of raw material in the value of a product is nearly $30 \%$ (ranging from $42 \%$ high to $5 \%$ low).

- The extent of value addition as percentage of prices earned by the artisan is around $32 \%$. (Only one-third is the artisan earning, nearly two-thirds is the sum total of expenses and overheads distributed between middlemen, transport, marketing, display and promotion, etc.).

- The difference between average price earned by the artisan and that at which the product is being sold in the local market is more than $35 \%$.

The second most important economic activity in these hill states after agriculture is handloom and handicrafts. Secondary data highlight the distribution of the handicraft clusters comprising of 250-300 members each, in the North eastern states (Table 1) and Handicraft projects extended to artisans amongst the different north east states in India (Table 2). 


\begin{tabular}{|c|c|c|c|c|}
\hline State & $\begin{array}{c}\text { Total } \\
\text { Districts }\end{array}$ & $\begin{array}{c}\text { District where } \\
\text { cluster exists }\end{array}$ & Cluster & $\begin{array}{c}\text { District } \\
\text { Covered }\end{array}$ \\
\hline Meghalaya & 07 & 04 & 11 & 03 \\
\hline $\begin{array}{c}\text { Arunachal } \\
\text { Pradesh }\end{array}$ & 16 & 08 & 09 & 08 \\
\hline Assam & 27 & 21 & 26 & 21 \\
\hline Manipur & 09 & 09 & 22 & 09 \\
\hline Mizoram & 08 & 03 & 04 & 03 \\
\hline Nagaland & 08 & 08 & 17 & 07 \\
\hline Tripura & 04 & 04 & 61 & 04 \\
\hline
\end{tabular}

Table 1: List of Handicrafts cluster in North Eastern states in India

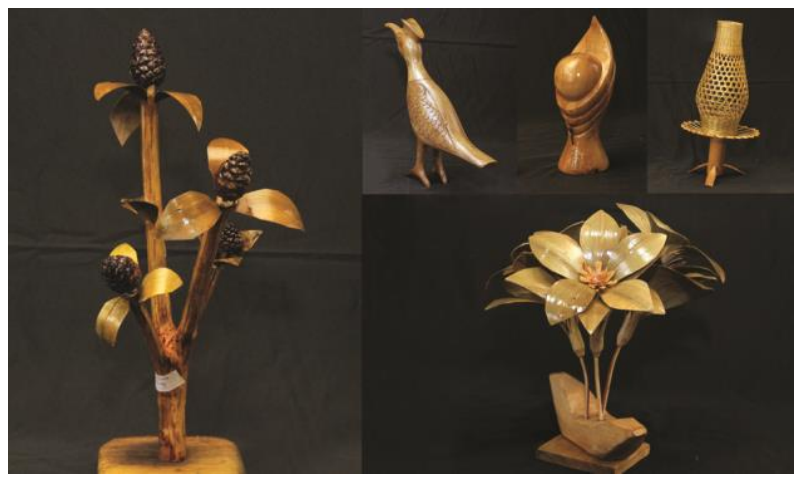

Fig. 2: The products that craftsmen brought were decorative and display products, as well as products what they make traditionally.

\begin{tabular}{|c|c|c|c|c|}
\hline State & $\begin{array}{c}\text { Total } \\
\text { Districts }\end{array}$ & $\begin{array}{c}\text { District where } \\
\text { cluster exists }\end{array}$ & Cluster & $\begin{array}{c}\text { District } \\
\text { Covered }\end{array}$ \\
\hline Meghalaya & 07 & 04 & 11 & 03 \\
\hline $\begin{array}{c}\text { Arunachal } \\
\text { Pradesh }\end{array}$ & 16 & 08 & 09 & 08 \\
\hline Assam & 27 & 21 & 26 & 21 \\
\hline Manipur & 09 & 09 & 22 & 09 \\
\hline Mizoram & 08 & 03 & 04 & 03 \\
\hline Nagaland & 08 & 08 & 17 & 07 \\
\hline \multicolumn{7}{|c|}{ Tripura } & 04 & 04 & 61 & 04 \\
\hline $\begin{array}{l}\text { In addition Resource Centre has been set up by the } \\
\text { Government at Imphal, Manipur and Guwahati, Assam. } \\
\text { Source: Working Group Report on Handicrafts for 12 } \\
\text { Ministry of Textiles, Govt. of India, 2012 }\end{array}$ \\
\hline \multicolumn{5}{|c|}{}
\end{tabular}

Table 2: List of Handicrafts Project sanctioned and artisan coverage in North Eastern states in India

\section{Design led interventions in the bamboo crafts of Me- ghalaya: A case example}

The Office of the Directorate of Commerce and Industries (DCIC), Government of Meghalaya, is a state level entity under the Ministry of Industry and Commerce. It is responsible for handicraft promotion and craft cluster development in the state of Meghalaya. DCIC approached the Department of Design, IIT Guwahati to undertake a workshop in training the craftsmen in new product development. The IIT design team comprising of three faculty, three artisans and 12 senior design students, took this opportunity to study and understand the current state of bamboo craft practices amongst identified craft clusters in the four

districts of Meghalaya. They organized a brainstorming workshop in the Office of the DCIC, Shillong and invited the concerned stakeholders. Participants included 80 artisans, $14 \mathrm{DCIC}$ officials and field managers, entrepreneurs and professional designers working with crafts community. Information was gathered through Interviews and discussions.

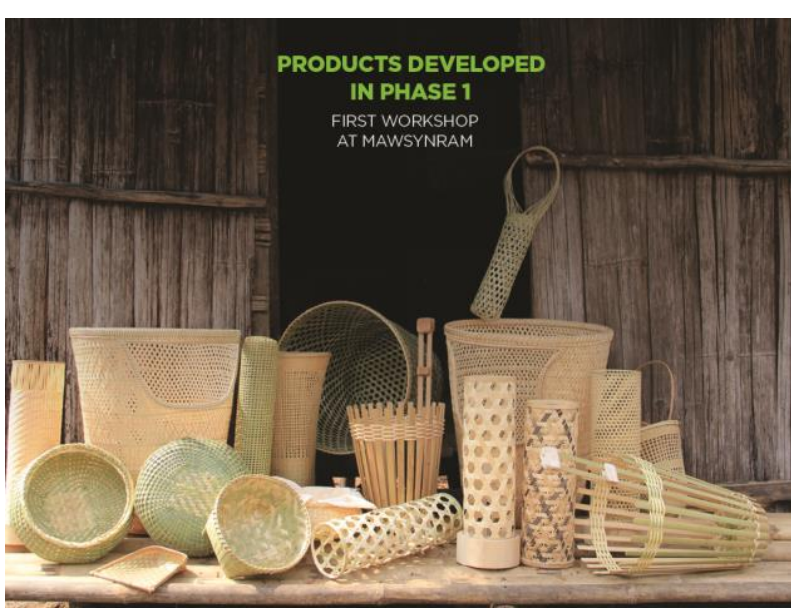

Fig. 3: The range of products that were designed during the field workshops. All Products use the RTI Molds to design and train the craftsmen. The weaving skills of the craftsmen were retained in the weave of the products.
Photo documentation was undertaken of the existing range of products made at the craft clusters. Contact addresses of the participants were gathered to enable subsequent interactions.

The information gathered from the brainstorming session helped to understand issues and problems in bulk production at the grassroots level. Craftsmen have different skills and make only what they are good at and in small numbers using traditional tools. These products were mostly decorative and suitable for local use. They sold the products at the local weekly market as they could get money upfront. Unaware of the needs of the urban markets, these skilled craftsmen did not realise the potentials and design intervention in products could fetch better value and price. One entrepreneur attempted to engage in this attempt withdrew complaining that the craftsmen failed to meet his business commitment for bulk orders received from a retailer in a city.

"I got an order for 10,000 baskets, but as the number increased the quality of the baskets made were of poor quality and were rejected."

The design team identified scalability and quality check as the challenge faced in this intervention. 
It required modelling an intervention that considered the entire product life cycle and integrated them in a holistic manner. Considering the insights from the brainstorming session, a quick field study was also made with two leading retail outlets in Mumbai to gather the scope of sales for utilitarian products. It was found that there was a very high potential for "hand Made" craft products for contemporary lifestyle amongst urban markets.

A new trend in online marketing of handicraft products was rapidly emerging in the Indian market. Urban-markets showed a high demand for functional handicraft products of everyday use. Middle income urban consumer particularly preferred functional and utilitarian items like fruit baskets, roti (bread) baskets, paper waste bins, laundry baskets, trays, photo frames, lamp shades, etc. These were presently being sourced in bulk from China and Malaysia. These could be developed as a replacement for these items.

A disruptive transformation could be achieved through new product development and brand building. This would address issues of design development of a new range of bamboo products that will aim to meet aspirations and demands of an urban market. The following products were shortlisted for design and development:

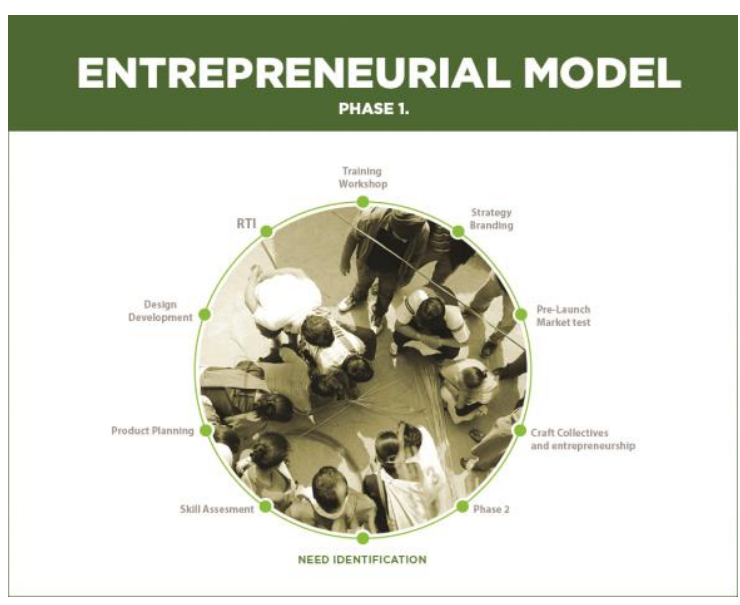

Fig. 4: PHASE 1. The nine stage process visualised to create a model of holistic intervention
- Roti / Bread basket

- Paper basket

- Laundry basket

- Lighting shades

- Fruit basket

- Gift hampers

\section{Methodology}

The above study resulted in outlining the approach and nine stage methodology the design team conceived it would follow during the rest of the development process.

With these inputs the design team conceptualized the first set of utilitarian products that included (bread basket, laundry basket and paper baskets). Following this the design team planned its first on-site craft workshop on February 18-21, 2015 at village Mawkaphan in the Mawsynram block. During the first field based design workshop at Mawsynram, the design team wanted to ensure that the crafts cluster would be able to deliver both quality and quantity of production in a limited timeframe. To ensure this it encouraged the cluster by placing a batch order for them to deliver in a time period of two weeks. The aim was to give them confidence in entrepreneurship. Payment for their efforts was committed by giving them an advance payments towards purchase of raw material and indicating the price of purchase for each item. This experiment proved very successful when the design team received the first delivery after the stipulated two weeks and the craftsmen were paid for their efforts immediately. It also helped to build mutual trust between the design team and the craft community.

It was evident that a holistic approach in new product development, marketing and design intervention leading to new range of products need to be developed. These could be introduced through a brandingand marketing plan. However an intervention had to make inclusive an approach that had continuity with the existing skills of the craft community. Such design interventions must make this a strength for its acceptance to the local craft community.

\section{tion (RTI) model of intervention:}

Development of productivity enhancing tools following Restricted Technology Interven-

To ensure consistency in quality and standardization in size of the products the IIT design team decided to introduce productivity enhancing means through the introductions of easy to make molds, jigs and fixtures.

1. Development of molds and workstation was undertaken keeping the following factors in mind: Ease of fabrication of the molds that are long lasting and can be fabricated at the village level using locally available materials and processes.

2. Introduce easy to understand assembly methods.

3. Human factors consideration in terms of safety and human comfort during use.

4. Processes for steam bending of bamboo strips must be developed using standard components that are readily available in the market. 

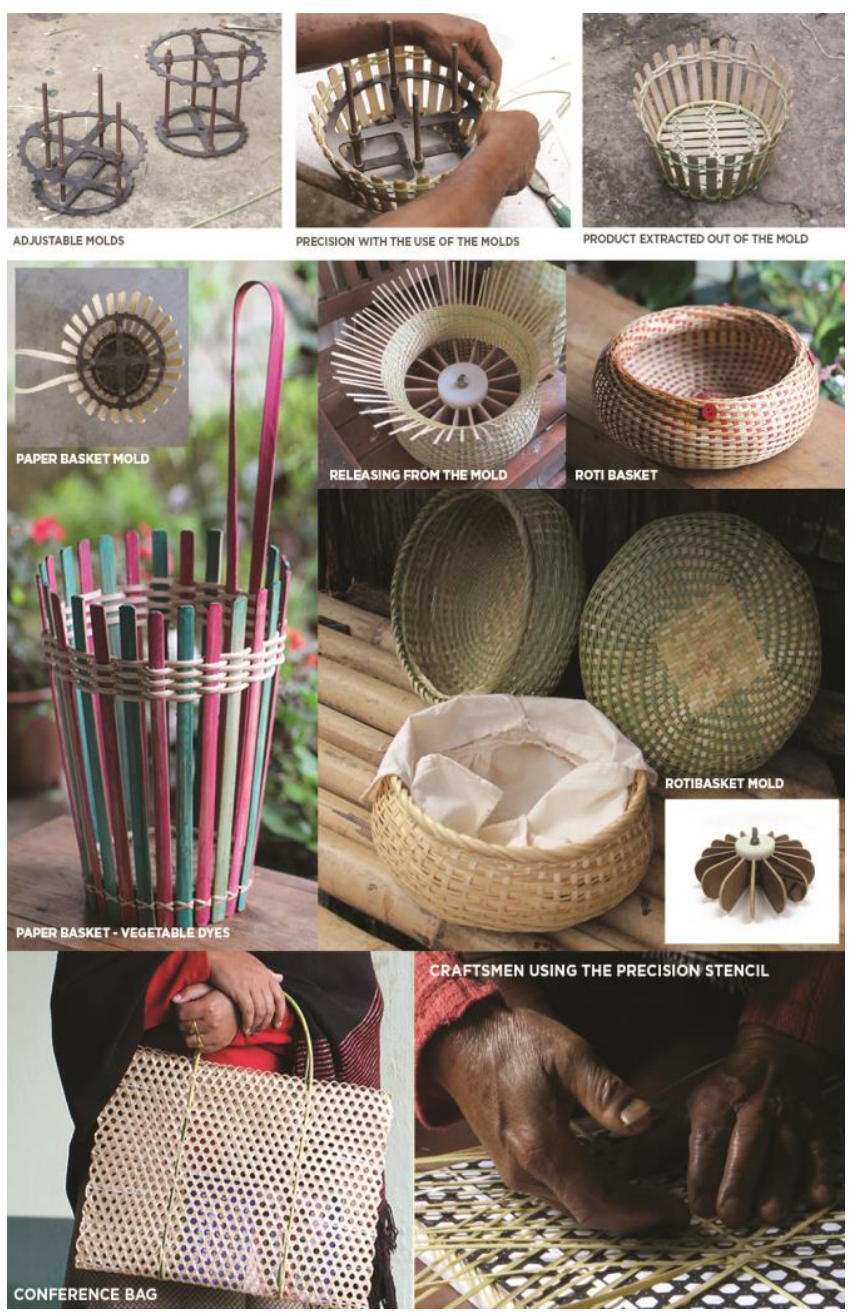

Fig. 5: Restricted technology intervention and the range of products developed under the brand SHKEN with improvisation in the molds.
The first set of four molds was designed one each for the roti basket, the laundry basket, lamp shade and the paper basket. This formed a very crucial exercise in achieving the desired shapes and form for the new product range developed. It also ensured the desired volumes of production at a competitive price range to meet expectations of a large urban market. All the products that were developed had a unique identity of the region and the craft cluster. They incorporated design features that drew upon the skill sets the different artisan community presently processed. During the training program they found ready acceptance by the craftsmen. The 'easy to make' molds, jigs and fixtures helped to enhance quality and quantity of production keeping locally available fabrication skill sets and processes. It introduced a method of intervention in the handicraft sector that can enhance the market potential of these high value hand-made products. The design team coined the term 'Restricted Technological Intervention (RTI) Method for this novel approach. Further to achieving effective communication the design team planned the design of visual aids and instructional videos that could help craftsmen to overcome language barrier and encourage peer self learning during the making process.

The plans for the next set of ten field-based Training program were finalized, one each at the district towns of Mawphlang, Pynsurla, Shillong, Mawkyrwat, Mairang, Nongpoh, Jowai, Nongstoin, Tura, and Williamnagar. The design team outlined the work plan in the field at each craft cluster and the training inputs to be given to them. Village craft clusters were grouped and invited to
ducts and productivity enhancing methods using the participate and trained for the first time to the new range of products and productivity enhancing
newly designed molds, jigs and fixtures. During these workshop they were also introduced to:

1. Techniques in treatment of bamboo to overcome problems of post production fungal attacks on the raw material.

2. To achieve consistency in quality, the use of simple hand tools and mechanically operated sizing machines like width sizer; simple jigs and fixtures etc. must be introduced.

3. To bring diversity and choice for the customer in the new product range techniques in coloring bamboo slivers must be introduced.

Based on the success of the series of ten field-based experiments, the design team planned two Production workshops at IIT Guwahati. A spirit of the strength of a craft collective could be shared and experienced for the first time when all the participants attending the field based training workshop from the different clusters met together for the first time during the two workshops. All were producing the same products using the same set of productivity enhancing molds, jigs and fixtures. The design team could talk with them together to help them to realise the value and potential their products could fetch if they worked as a collective. Talks were arranged in support schemes that could help them to organize themselves at their village clusters. The novelty of the holistic approach where the focus on 'people first' was very evident. It had the reassurance that it could be scaled up for volumes of production should these teams reorganize themselves into a collective group. It logically laid the road map for the branding of this new initiative.

\section{products of Meghalaya}

\section{Planning for the front end - Marketing and branding strategy for bew range of handicraft}


Fig. 6: The final logo for the Brand with the Tagline
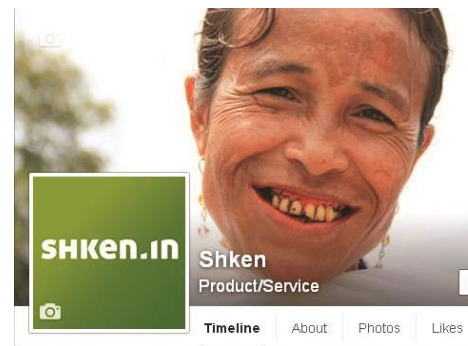

Fig. 7: Promotion of the Craftsmen through social media

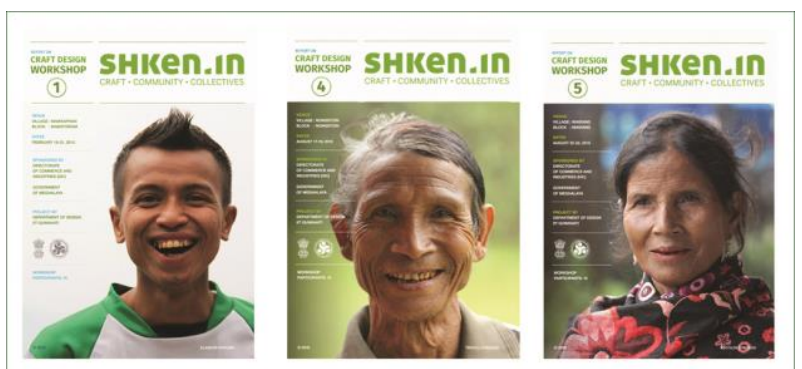

Fig. 8: Shken newsletters documented the workshops and always kept the craftsmen at the forefront

\section{Branding}

An effective communication strategy that was in tune with the emerging trend of online marketing seemed very logical to pursue. Product differentiation could be effectively achieved by strategically capturing the ethos of 'people first' as the face of this novel craft collective initiative. The factors that formed the guiding ethos in building the brand included:

1. The brand name needed to have a regional feel to give it an identity of the state of Meghalaya.

2. The logo and style to be developed had to be contemporary, unique and appealing. Embossing, etching on Bamboo should be possible therefore a bold font was chosen for the identity.

3. The brand needed to have a contemporary and 'Glocal' sound to it. The tagline (CRAFT. COMMUNITY. COLLECTIVE) reflected the ethos of the holistic concept viz.- to celebrate the craft, get the communities together and forming a collective. The web URL was chosen as SHKEN.IN and not .COM to align with objectives of MAKE IN INDIA campaign by the government.

4. The color scheme has to celebrate the feeling of being 'natural and handmade therefore we chose green for the logotype.

5. Social media promotion - where craftsmen were positioned as heroes by coining the term Shken Heroes. Facebook page was created and a glimpse of the project was shared with the online community.

6. After the conclusion of each workshop, one copy of the documented newsletter were posted to the village head of the respective cluster to showcase a sense of pride amongst the artisans.

\section{Project Implementation - Planning Entrepreneurial Intervention Model for Phase 2}

The project at this stage has followed the project methodology and realised in a planned manner the first 8 stages of Phase 1 as outlined in figure 04 . These phases included:

- Need Identification

- Skill Assessment

- Product Planning

- Design Development

- Production intervention following RTI

- 10 Field based Training programs

- 2 production workshops

- Building a strategy and Branding for effective communication and promotion and doing a prelaunch Market test

The pre-launch market test showing positive results has helped build a firm foundation for planning the implementation 


\section{ENTREPRENEURIAL MODEL}

\section{PHASE 2. (PROPOSED)}

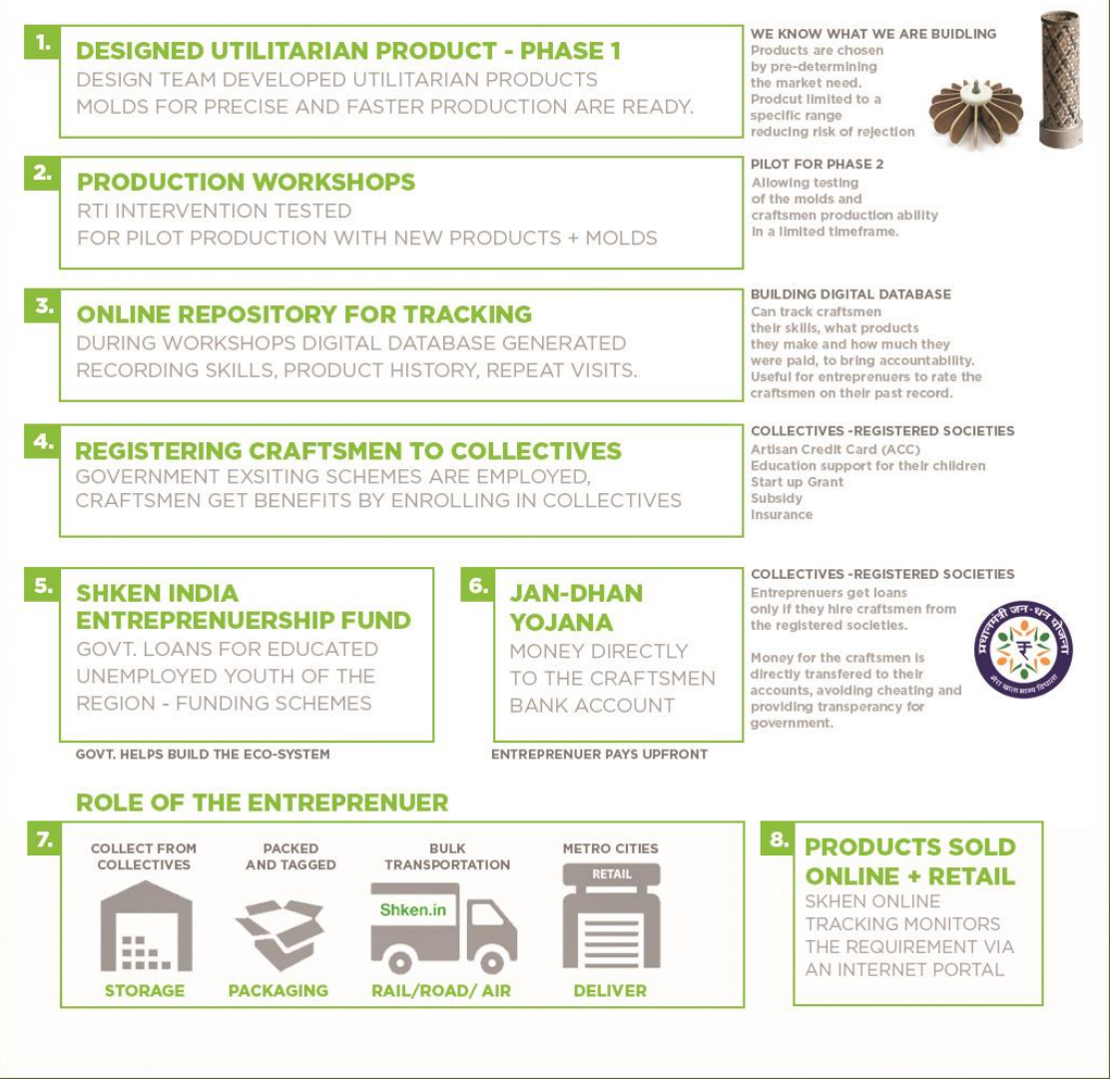

Fig. 9: PHASE 2. The proposed model of the entrepreneurial intervention. of the Entrepreneurial intervention model for Phase 2 of the project. During this stage the modalities of supply chain management, aspects of transportation and formation of the Craft Collectives (in alignment with the policies of the government) has been outlined as shown in figure 9 below. The proposal has received a very positive response from the Government of Meghalaya.

\section{Conclusions}

Engaging with the craftsmen at their place of work during the ten field based workshops has been an experience. It has enriched this design led initiative in the domain of crafts to be grounded and realistic in its approach. The focus on 'people first' perspective has brought realization that going into the field, engaging with the community, learning the challenges they would actually experience has resulted in bringing credibility and acceptance with the people involved. Modelling of an approach including production workshops has

helped the craftsmen to experience the issues related to production and what care has to be taken while making objects in large quantities. The design got insights on design and development of molds. Appropriate refinements and improvisations to production processes were made to appropriately introduce variations in the product design features. Knock down features had to be thought of in the molds to facilitate ease of transportation to the village centre.

Concepts in managing the production and delivery mechanism needed deviations from established approaches. Establishing trust and acceptance by the artisanal community was primary to the success of this model. Ensuring that there is a cycle of production by placing orders with the craftsmen and facilitating direct and immediate payment to the craftsmen was crucial in such an intervention. These outcomes were far more productive compared to the earlier scenario where there was no follow up after the conventional design workshops conducted earlier. The design team has learnt the challenges of planning and design for the Indian handicrafts of the north-east. This activity being the second most important economic activity of this region, the importance of introducing a novel RTI approach in production of crafts for the NE cannot be over emphasized. Furthermore, the introduction of online marketing for high value handicrafts of Meghalaya has potential to bring the handicraft community in such remote locations to the attention of national and international audience. Celebrating the artisan community of the region by branding cannot be over emphasized.

The Government of India, recognizing the need for a rapid transformation of the manufacturing sector for the economic growth of the nation, has recently introduced schemes such as 'Make in India' and 'Digital India'. The design team is convinced that the approach outlined as a model (outlined in figure 9) for the bamboo artisan community of Meghalaya has the potential to be scaled up for successful implementation. The proposal has convinced the Government of Meghalaya to go into the second phase of implementation of this project. It can result in the disruptive intervention that this unorganized but important sector urgently needs for its revival. 


\section{References}

Ranjan, M.P., Iyer, N. and Pandya, G. (1986) Bamboo and Cane Crafts of North East India, Ahmedabad: NID Ministry of Human Resource and Development, Govt. of India (2014), Design Manifesto, IDC, IIT Bombay. Ministry of Textiles, Govt. of India. (2012), Report of the 'Working Group Report on Handicrafts for 12th Five Year Plan'.

North East Development and Finance Corporation (2001), Report 23 'Cll initiative to improve the handloom and handicraft products of North East', Report 23, NEDFI

Web:(http://www.nedfi.com/sites/all/themes/industry/ar/tedf/exe_summary/23_Executive_Summary_of_ClI_h andloom_study.pdf, (23 Dec 2015)

\section{Biographical note}

Mandar Rane is an Associate Professor at Industrial Design Centre (IDC), School of Design, Indian Institute of Technology Bombay and is the coordinator of the Communication Design program. He has been teaching for more than a decade and with focus on semantics and communication theory. You can see his academic as well as professional work on his personal website http://www.mrane.com

Ravi Mokashi Punekar is Professor in Design and Dean (External Relations) at Indian Institute of Technology Guwahati, Assam, India. He has 30 years of experience as a design educator. He spent 15 years teaching at the National Institute of Design Ahmadabad, heading the Faculty of Industrial Design before he joined IIT Guwahati as one of the founder faculty members setting up their Design program. He has engaged in major projects related to product design, sustainability and social innovation. Research in material culture, design and Indian handicrafts has been a subject of keen interest as also Design pedagogy and education .

Avinash Shende is Assistant Professor at Department of Design, Indian Institute of technology Guwahati. He is graduated from Domus Academy, Milan and he is teaching design since last 10 years. He owns several international design and innovation awards. He worked with companies and organisations like UNIDO and UNDP for uplifting livelihood of artisans in bamboo sector. 